\title{
IDENTIFIKASI PERUBAHAN KONTUR KEDALAMAN LAUT DIPERAIRAN SEKITAR ANAK GUNUNG KRAKATAU PASCA ERUPSI TAHUN 2018
}

\author{
Dedy Wirasetiyawan ${ }^{1}$, Nawanto Budi Sukoco ${ }^{2}$, Nur Riyadi ${ }^{3}$, Dikdik Satria Mulyadi ${ }^{4}$ \\ ${ }^{1}$ Mahasiswa Program Studi Hidrografi, STTAL \\ ${ }^{2}$ Peneliti pada Program Studi Hidrografi, STTAL \\ ${ }^{3}$ Peneliti pada Komando Armada 1 TNI Angkatan Laut \\ ${ }^{4}$ Peneliti pada Pusat Hidrografi dan Oseanografi Angkatan Laut, Pushidrosal \\ Penulis: ragiel462.dw@gmail.com
}

\begin{abstract}
ABSTRAK
Krakatau (Rakata) adalah kepulauan vulkanik yang masih aktif yang terletak di Selat Sunda, antara Pulau Jawa dan Sumatera. Pada tahun 1927 atau kurang lebih 40 tahun setelah meletusnya Gunung Krakatau, muncul gunung api yang dikenal sebagai Anak Krakatau dari kawasan kaldera purba tersebut yang masih aktif dan tetap bertambah tingginya. Penyebab semakin tingginya gunung itu disebabkan oleh material yang keluar dari perut gunung baru itu. Pada penelitian ini dititik beratkan pada identifikasi perbandingan perubahan kontur kedalaman perairan disekitar Anak Gunung Krakatau sebelum dan pasca erupsi tahun 2018.

Data penelitian ini berupa data sekunder Multibeam Echosounder (MBES) yang diperoleh dari hasil survei KRI Spica-934 di Perairan Selat Sunda atau di sekitar Anak Gunung Krakatau pasca erupsi tahun 2018 menggunakan MBES EM 2040 dan EM 302. Data yang diperoleh kemudian diolah menggunakan software Charis Hips and Sips selanjutnya dioverlay dengan Lembar Lukis Teliti (LLT) tahun 2016. Dari hasil penelitian didapatkan bahwa terjadi perubahan kontur kedalaman laut di area sekitar Anak Gunung Krakatau pasca erupsi tahun 2018 yang mengakibatkan pendangkalan hampir diseluruh area Anak Gunung Krakatau, terutama di bagian selatan dan barat dimana terdapat garis pantai yang menyempit akibat longsoran, selain itu berdasar data hasil olahan terdapat pola garis kontur kedalaman laut yang mendekati garis pantai.
\end{abstract}

Kata Kunci : Krakatau, Multibeam Echosounder, Pemeruman, Kontur Kedalaman

\begin{abstract}
Krakatau (Rakata) is an active volcanic archipelago located in the Sunda Strait, between Java and Sumatera. In 1927 or about 40 years after the eruption of Mount Krakatoa, a volcano known as Anak Krakatau from the ancient caldera region was still active and continued to increase in height. The cause of the height of the mountain was caused by material coming out of the belly of the new mountain. This research focuses on identifying comparative changes in contour changes in the waters around the Anak Krakatau volcano before and after the eruption in 2018.

The research data are secondary Multibeam Echosounder (MBES) data obtained from the KRI Spica-934 survey in the waters of the Sunda Strait or around Anak Krakatau Mountain after the eruption in 2018 using MBES EM 2040 and EM 302. The data obtained were then processed using Charis Hips software. and Sips was then overlaid with Lembar Lukis Teliti (LLT) in 2016. From the results of the study it was found that there was a change in sea depth contour in the area around the Anak Krakatau Mountain after the eruption in 2018 which resulted in silting of almost the entire Mount Krakatau sub-area, especially in the southern part and west where there is a narrower coastline due to landslides, besides that based on processed data there is a pattern of sea depth contour lines approaching the coastline.
\end{abstract}

Keywords : Krakatau, Multibeam Echosounder, Sounding, Depth Contour 


\section{PENDAHULUAN}

Krakatau (Rakata) adalah kepulauan vulkanik yang masih aktif yang terletak di Selat Sunda, antara Pulau Jawa dan Sumatera. Pulau Rakata, yang merupakan satu dari tiga pulau sisa Gunung Krakatau Purba kemudian tumbuh sesuai dengan dorongan vulkanik dari dalam perut bumi yang dikenal sebagai Gunung Krakatau (atau Gunung Rakata) yang terbuat dari batuan basaltik.

Multibeam Echosounder (MBES) adalah alat yang dapat digunakan untuk mengukur banyak titik kedalaman secara bersamaan yang didapat dari suatu susunan tranduser (tranduser array) (Lekkerkerk, 2006). MBES merupakan alat yang digunakan dalam proses pemeruman suatu survei hidrografi. Sistem pada MBES merujuk pada sekumpulan sensor yang dipasang pada suatu wahana survei yang digunakan secara bersamaan untuk mendapatkan pengukuran kedalaman seketika.

Pada penelitian ini dititik beratkan pada identifikasi perbandingan perubahan kontur kedalaman perairan disekitar Anak Gunung Krakatau sebelum dan pasca terjadinya erupsi tahun 2018. Data penelitian ini berupa data sekunder MBES yang diperoleh dari hasil survei KRI Spica-934 di perairan Selat Sunda atau disekitaran Anak Gunung Krakatau.

\section{METODOLOGI PENELITIAN}

Jenis penelitian yang digunakan adalah metode kualitatif dengan pendekatan komparatif. Metode penelitian kualitatif adalah penelitian tentang riset yang bersifat deskriptif dan cenderung menggunakan analisis. Proses dan makna (perspektif subjek) lebih ditonjolkan dalam penelitian kualitatif.

\subsection{Sumber Data}

Penelitian Ini menggunakan sumber data sekunder berupa data batimetri dari survei yang dilaksanakan oleh KRI Spica-934 tahun 2019 di Selat Sunda tepatnya di perairan sekitaran Anak Gunung Krakatau serta data dari Dishidro Pushidrosal sebelum terjadi erupsi pada tahun 2018. Data yang diambil terdiri dari tiga data yaitu:
a. Data Batimetri
b. Data pasang surut
c. Data Sound Velocity Profile (SVP)

\subsection{Subyek Penelitian}

Subyek dari penelitian ini adalah tim survei dan pengawak KRI Spica - 934 selaku narasumber serta Dishidro Pushidrosal sebagai tempat pengolaahan data. Pengambilan data dilaksanakan pada saat survei Selat Sunda yang dilaksanakan oleh KRI Spica-934 pada tahun 2019.

\subsection{Obyek Penelitian}

Penelitian ini menggunakan objek berupa dasar kedalaman perairan Anak Gunung
Krakatau di Selat Sunda yang mengakibatkan terjadinya pendangkalan pasca erupsi Anak Gunung Krakatau tahun 2018. Area yang digunakan adalah peta laut Indonesia nomor 71 A tahun 2016, skala 1:100.000 dengan koordinat 6030'00"S ; $105^{\circ} 20^{\prime} 00^{\prime \prime} T-5^{0} 40^{\prime} 00^{\prime \prime} S$; $106^{\circ} 00^{\prime}$ $00 " \mathrm{~T}$

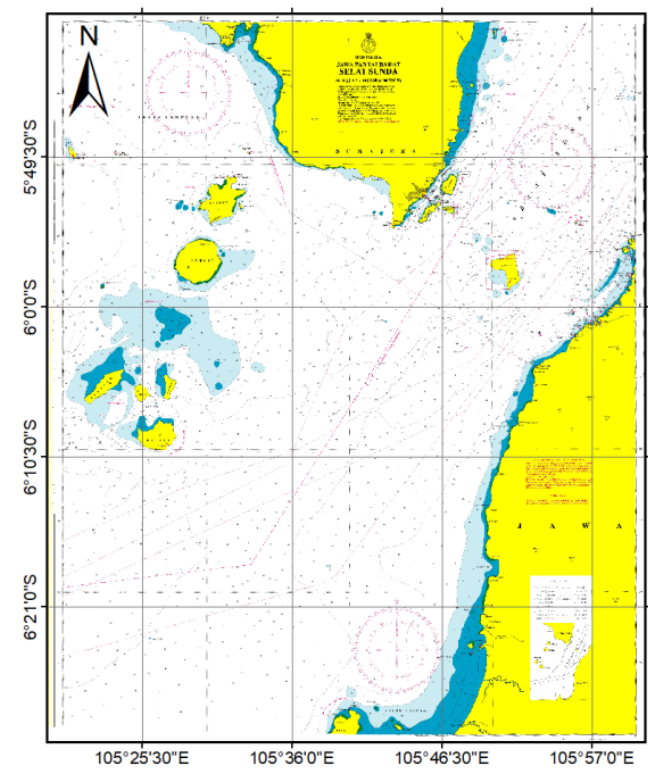

Gambar 2.1 Peta Jawa Pantai Barat Selat Sunda

(Sumber: Pushidrosal, 2016)

\subsection{Teknik Pengumpulan Data}

Dalam teknik pengumpulan data dilakukan dalam kurun waktu yang bersamaan, terdiri dari tiga data yang berbeda beda, yaitu :

a. Pengambilan Data Batimetri MBES

Pengambilan data batimetri dilakukan menggunakan KRI Spica-934 dengan instrument MBES EM 302 single head dan SV KRI SPICA-934 dengan instrument MBES EM 2040 dual head.

b. Pengambilan Data Pasang Surut (Tide)

Data pasang surut yang digunakan pada penelitian ini merupakan data primer yang diperoleh dari lokasi stasiun pasut berada di dekat area survei yaitu Dermaga Pulau Sebesi menggunakan Palem Pasut panjang $8 \mathrm{~m}$ dan TideValeport yang diletakkan jadi satu dengan rambu ukur. Dilaksanakan pada tanggal 14 Februari 2019 pikul 00:00 WIB/GMT+7 hingga 14 Maret2019 pukul 14:00 WIB/GMT+7 selama 29 piantan interval data 1 jam dengan posisi 556'10.94114"S-105³0'41.42621"T (WGS84).

C. Pengambilan Data Sound Velocity Profile

Data SVP diperoleh melalui sebuah alat yang disebut MIDAS SVX2. Pengambilan data SVP pada tanggal 07 
dan 08 Maret 2019. Instrumen ini memiliki beberapa sensor yang mampu merekam (recorded) parameter oseanografi seperti nilai konduktivitas, suhu dan tekanan. Salah satu keuntungan dari penggunaan instrumen ini adalah mampu dioperasikan secara portable.

\subsection{Instrumen Pengumpulan Data}

Data batimetri yang didapatkan adalah data MBES yang berasal dari Kongsberg EM 2040 dual head dan SV EM 302 single head serta dilengkapi dengan stabilizer oleng, angguk dan penyimpangan haluan. Pada saat akuisisi frekuensi yang digunakan $400 \mathrm{KHz}$, Coverage Angle yang digunakan $\pm 60^{\circ}$.

Tabel 2.1 Alat dan Bahan yang Digunakan Dalam Survei MBES

\begin{tabular}{|c|c|c|}
\hline $\begin{array}{c}\text { Alat dan } \\
\text { Bahan }\end{array}$ & Jenis & Keterangan \\
\hline $\begin{array}{l}\text { Multibeam } \\
\text { Echosounder }\end{array}$ & $\begin{array}{l}\text { Kongsberg EM } \\
2040 \text { dual } \\
\text { head }\end{array}$ & $\begin{array}{l}\text { Akuisisi data } \\
\text { batimetri }\end{array}$ \\
\hline $\begin{array}{l}\text { Multibeam } \\
\text { Echosounder }\end{array}$ & $\begin{array}{l}\text { Kongsberg EM } \\
302 \text { single } \\
\text { head }\end{array}$ & $\begin{array}{l}\text { Akuisisi data } \\
\text { batimetri }\end{array}$ \\
\hline DGNSS & $\begin{array}{l}\text { SEA STAR } \\
\text { RECEIVER } \\
3610\end{array}$ & $\begin{array}{l}\text { Untuk } \\
\text { penentuan } \\
\text { posisi }\end{array}$ \\
\hline $\begin{array}{l}\text { Motion } \\
\text { sensor }\end{array}$ & Seapath 330 & $\begin{array}{l}\text { Untuk sistem } \\
\text { penentuan } \\
\text { posisi secara } \\
\text { real time }\end{array}$ \\
\hline Sensor SV & $\begin{array}{l}\text { VALEPORT } \\
\text { Mini SVS }\end{array}$ & $\begin{array}{l}\text { Untuk } \\
\text { mengkoreksi } \\
\text { kecepatan } \\
\text { gel. akustik } \\
\text { secara real } \\
\text { time }\end{array}$ \\
\hline CTD & MIDAS SVX2 & $\begin{array}{l}\text { Untuk } \\
\text { mengambil } \\
\text { data } \\
\text { kecepatan } \\
\text { suara }\end{array}$ \\
\hline Pasang Surut & $\begin{array}{l}\text { Mini Tide dan } \\
\text { Palem Pasut }\end{array}$ & $\begin{array}{l}\text { Untuk } \\
\text { mengambil } \\
\text { data Pasang } \\
\text { surut }\end{array}$ \\
\hline $\begin{array}{l}\text { Software } \\
\text { navigasi dan } \\
\text { akuisisi data }\end{array}$ & $\begin{array}{l}\text { Seafloor } \\
\text { Information } \\
\text { System (SIS) }\end{array}$ & $\begin{array}{l}\text { Untuk } \\
\text { mengontrol, } \\
\text { menampilka } \\
\text { n data } \\
\text { navigasi dan } \\
\text { menampilka } \\
\text { n sistem } \\
\text { MBES } \\
\text { secara real } \\
\text { time }\end{array}$ \\
\hline $\begin{array}{l}\text { Software } \\
\text { olah data }\end{array}$ & $\begin{array}{l}\text { CARIS HIPS } \\
\text { and SIPS }\end{array}$ & $\begin{array}{l}\text { Untuk } \\
\text { mengolah } \\
\text { dan }\end{array}$ \\
\hline
\end{tabular}

\begin{tabular}{|l|l|l|}
\hline batimetri & & $\begin{array}{l}\text { menampilka } \\
\text { n data } \\
\text { batimetri }\end{array}$ \\
\hline $\begin{array}{l}\text { Software } \\
\text { editing data }\end{array}$ & $\begin{array}{l}\text { Microsoft } \\
\text { Excel \& } \\
\text { Notepad }\end{array}$ & $\begin{array}{l}\text { Untuk } \\
\text { mengedit } \\
\text { dan } \\
\text { menampilka } \\
\text { n data pasut } \\
\text { dan SVP }\end{array}$ \\
\hline $\begin{array}{l}\text { Wahana } \\
\text { Survei }\end{array}$ & $\begin{array}{l}\text { KRI SPICA- } \\
\text { 934 SV KRI }\end{array}$ & $\begin{array}{l}\text { survei } \\
\text { tempat } \\
\text { Seralatan } \\
\text { SPICA-934 }\end{array}$ \\
& & $\begin{array}{l}\text { akustik } \\
\text { terpasang }\end{array}$ \\
\hline
\end{tabular}

\subsection{Teknik Analisis Data}

Setelah data yang akan diteliti terkumpul maka langkah pertama yang dilaksanakan yaitu pengolahan data pasut, sound velocity dan batimetri kemudian dilanjutkan untuk uji kualitas data, setelah itu melaksanakan identifikasi dan yang terakhir menganalisis hasil data olahan tersebut.

\subsection{Waktu dan Tempat}

Pengambilan data dan akuisisi data dilakukan pada tanggal 12 Februari 2019 s/d 22 Maret 2019 di perairan Anak Gunung Krakatau, Selat Sunda dengan menggunakan peralatan survei KRI Spica - 934.

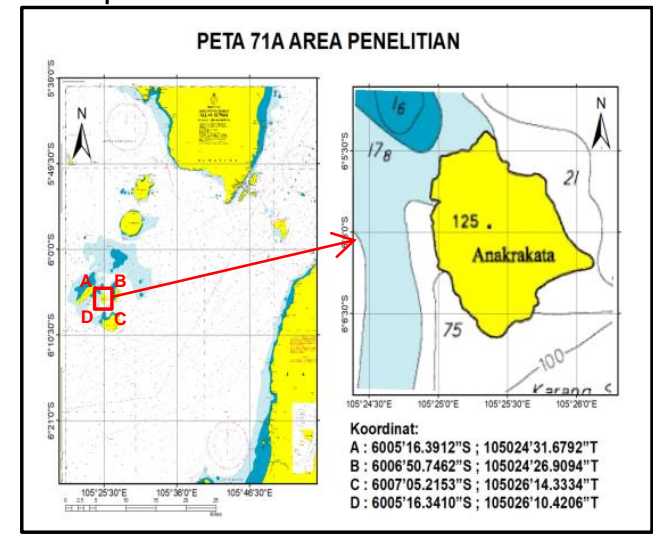

Gambar 2.2 Peta Area Penelitian

Lokasi tersebut dipilih karena sesuai dengan batasan masalah area perubahan kontur kedalam di perairan sekitar Anak Gunung Krakatau, Selat Sunda pasca terjadinya erupsi pada tahun 2018 yang kami bahas.

\subsection{Pengolahan Data}

Data penelitian di olah menggunakan software Caris Hips and Sips. Pengolahan data penelitian ini dilakukan di Dishidro Pushidrosal dan dikampus Sekolah Tinggi Teknologi Angkatan Laut (STTAL) Hidrografi, Ancol, Jakarta Utara, DKI Jakarta.

a. Pengolahan Data Pasang Surut Data pasang surut digunakan sebagai koreksi data batimetri, dimana 
data pasang surut yang sudah dikurangi nilai muka surutan. Metode penentuan Duduk Tengah Sementara (DTS) dan Muka Surutan (MS) menggunakan metode Admiralty. Data surutan yang digunakan disesuaikan dengan waktu pelaksanaan pengambilan data batimetri.

b. Pengolahan Data SVP

Data kecepatan suara ditampilkan dengan Sound Velocity Editor pada software CARIS HIPS and SHIPS. Sebelum ditampilkan dalam Sound Velocity Editor dilakukan pengaturan format penyusunan data kecepatan suara dalam Microsoft Excel, yaitu kolom pertama sebagai data kedalaman dan kolom kedua sebagai data kecepatan suara. File data kecepatan suara disimpan dengan format ".svp". Data tersebut kemudian ditampilkan dengan tools SVP editor.

c. Pengolahan Data Batimetri

$$
\text { Pengolahan data }
$$

MBES

menggunakan metode swath angle untuk mendapatkan kedalaman sesuai detail sapuan MBES dan software pengolahan menggunakan CARIS HIPS and SIPS. Pengolahan data penelitian ini dilakukan di Dishidro Pushidrosal dan kampus STTAL Hidrografi, Ancol, Jakarta Utara, DKI Jakarta.

\subsection{Uji Kualitas Pengukuran Kedalaman}

Pada setiap malaksanakan pengukuran kedalaman sering kali didapat nilai kedalaman yang bukan nilai sebenarnya, tetapi nilai outlier (rata-rata) sehingga perlu adanya uji kualitas (Quality Control). Batas toleransi kesalahan nilai beda kedalaman diatur dalam IHO SP 44 tahun 2008 dan SNI 7646-2010 dengan tingkat kepercayaan $95 \%$.

Koreksi dilakukan dengan cara membandingkan nilai kedalaman pada titik perpotongan (Cross Check) antara lajur melintang $\left(d_{l}\right)$ dengan lajur membujur $\left(d_{b}\right)$, sehingga didapat nilai penyimpangan kedalaman (S). Sebelum dilakukan koreksi dilakukan gridding menggunakan metode Weight Moving Average. Perhitungan nilai penyimpangan kedalaman menggunakan persamaan:

$$
S=d_{l}-d_{b}
$$

Keterangan :

$S$ : penyimpangan kedalaman

$d_{l}$ : kedalaman pada lajur melintang/utama

$d_{b}$ : kedalaman pada lajur membujur/silang

Standar minimum survei batimetri dinyatakan dengan tabel yang sudah sesuai dengan standar IHO SP-44 tahun 2008.

Tabel 2.2 Daftar Standart Minimum Survei Batimetri

\begin{tabular}{|c|c|c|c|c|}
\hline Orde & Spesial & $1 \mathrm{a}$ & $1 \mathrm{~b}$ & 2 \\
\hline Konstanta & $\mathrm{a}=0.25 \mathrm{~m}$ & $\mathrm{a}=0.5 \mathrm{~m}$ & $\mathrm{a}=0.5 \mathrm{~m}$ & $\mathrm{a}=1.0 \mathrm{~m}$ \\
& $\mathrm{~b}=0.0075$ & $\mathrm{~b}=0.013$ & $\mathrm{~b}=0.013$ & $\mathrm{~b}=0.023$ \\
\hline \multicolumn{4}{c}{ (Sumber: International Hydrographic } \\
Organization (IHO), 2008)
\end{tabular}

Menurut IHO SP-44 edisi 5 tahun 2008, pelabuhan dan alur pelayaran yang kritis berhubungan dengan kedalaman air di bawah lunas yang sangat minim menggunakan orde spesial dengan konstanta nilai $a=0.25$ dan nilai $\mathrm{b}=0,0075$. Perhitungan batas toleransi kesalahan (limit error) untuk pengukuran kedalaman perairan secara matematik dapat diperoleh persamaan :

$(2 \sigma)= \pm \sqrt{a^{2}+(b x d)^{2}}$

Keterangan :

$2 \sigma:$ nilai batas toleransi ketelitian kedalaman $(\mathrm{m})$.

$a$ :konstanta kesalahan kedalaman (m).

$b$ :faktor pengganti kesalahan kedalaman.

$d$ :kedalaman $(\mathrm{m})$.

\subsection{Diagram Alir}

Proses pengolahan dan analisis pada penelitian ini digambarkan pada diagram alis berikut ini

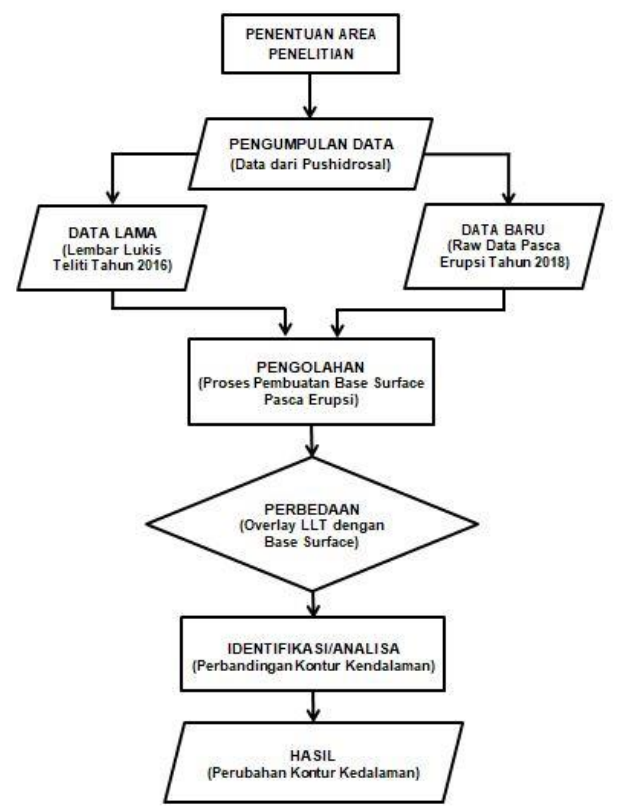

Gambar 2.3 Diagram Alir

\section{ANALISIS DATA DAN HASIL PENELITIAN \\ 3.1 Proses Alur Kerja Cube Pada Caris Hips and Sips}

Dalam melaksanakan pengolahan data bathimetri kami menggunakan pedoman alur kerja Cube pada Caris Hips and Sips seperti pada gambar. 




Gambar 3.1 Cube Workflow in Hips

Dari gambar diatas dapat dijelaskan bagaimana alur kerja dalam melaksanakan pengolahan data bathimetri. Berikut adalah keterangan dari tiap-tiap proses alur kerja Cube pada Caris Hips and Sips:

a. Create a Vessel File : mengatur posisi sensor dan ketidaktentuan (uncertainty) ke dalam kolom isian Vessel Reference.

b. Create a New Project : membuat struktur data Project - Vessel - Day.

c. Convert Raw Data : memasukkan Raw data kedalam format data HIPS.

d. Save Session : Menyimpan pekerjaan (data dan tampilan yang ada).

e. Sound Velocity Correction : Memasukkan dan mengedit sound velocity profiles dan mengaplikasikan koreksi.

f. Load Tide : Memasukkan data pasut (tide) dari 1 (satu) atau lebih stasiun pasut.

g. Merge:Mengkombinasikan/menggab ungkan informasi horisontal dan vertikal untuk memproduksi geo-referenced data.

h. Compute TPU : Menggunakan nilainilai uncertainty, dimasukkan kedalam HVF untuk menghitung total propagated uncertainty dari setiap titik perum.

i. Define New Field Sheets : Menentukan proyeksi peta dan lokasi data.

j. Generate BASE Surface (CUBE) : Data yang telah dikombinasikan (Merged) digunakan untuk memproduksi CUBE surface.

k. Data QC : Memeriksa sensor-sensor seperti navigation, gyro, heave dan sebagainya, jika permasalahan ditemukan pada BASE surface.

I. Automated Filters : Filter soundings menggunakan swath geometry dan/atau mengacu pada standar akurasi orde survei IHO.

$\mathrm{m}$. Process Subset Data : Validasi CUBE Surface dan mengedit georeferenced soundings secara langsung pada banyak lajur secara simultan, dimana CUBE surface telah mengalami kerusakan akibat erroneous soundings.

n. Recompute : Pemutakhiran (Updating) BASE Surface setelah data diperbaiki/diedit dan surface di validasi.

o. Finalize : Finalisasi BASE Surface untuk memastikan designated soundings diikutsertakan sampai dengan produk batimetri.

p. Create Product Surface: Membuat sebuah generalized product surface dari BASE surface.

q. Contours : Gunakan salah satu antara BASE Surface, product surface atau tile set untuk membuat kontur.

r. Sounding Selection : Gunakan sumber data yang paling menonjol (height source) untuk dipilih sebagai suatu perwakilan dari sounding set.

s. Export Data : Hasil pengolahan HIPS baik data kedalaman dan surfaces dapat di ekspor ke berbagai format data.

\subsection{Data Pendukung}

Data pendukung yang digunakan pada penelitian ini yaitu :

a. Peta Laut Indonesia Nomor 71A

Peta yang digunakan pada penelitian skripsi ini menggunakan Peta Laut Indonesia Nomor 71A yaitu peta Jawa Pantai Barat Selat Sunda yang diterbitkan oleh Pushidrosal tahun 2016 dengan skala $1: 100.000$

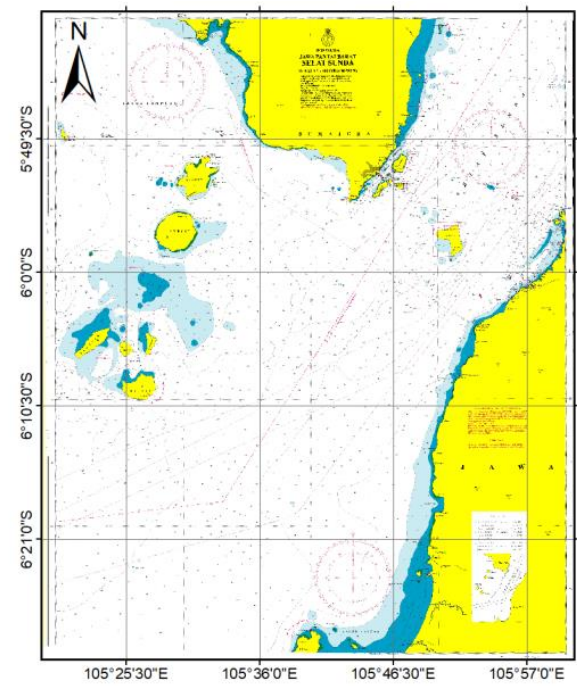

Gambar 3.2 Peta 71A Jawa Pantai Barat Selat Sunda

(Sumber: Pushidrosal, 2016)

b. Lembar Lukis Teliti (LLT) Selat Sunda

Pembanding penilitian kami ini menggunakan Lembar Lukis Teliti tahun 2016 sebelum terjadinya erupsi Anak Gunung Krakatau, data tersebut kami 
dapat dari Dishidro Pusidrosal yang kemudian akan kami overlay dengan data hasil olahan base surface penelitian yang kami kerjakan.



Gambar 3.3 Lembar Lukis Teliti (LLT) Anak Krakatau Tahun 2016 (Sumber: Pushidrosal, 2016)

\subsubsection{Data Bathimetri}

Pengumpulan data bathimetri yang kami lakukan untuk mendukung pengerjaan skripsi ini yaitu, berupa raw data hasil survei yang di laksanakan oleh seluruh pengawak KRI Spica934 selaku pelaksana pengambilan data dan dari Dishidro Pushidrosal berupa .all file. Pengambilan data dan akuisisi data dilaksanakan pada tanggal 12 Februari 2019 s/d 22 Maret 2019 di perairan sekitar Anak Gunung Krakatau, Selat Sunda, selain itu juga kami menggunakan data lama berupa LLT (Lembar Lukis Teliti) tahun 2016 dengan format file berbentuk des dari Dishidro Pushidrosal sebagai data pembanding.

\subsubsection{Pengolahan Data Pasut}

Data yang diperoleh dari hasil pengamatan menggunakan palem pasut dengan pannjang $8 \mathrm{~m}$ dan tide selama 29 hari dimulai dari tanggal 14 Februari 2019 pukul 00:00 waktu lokal (WIB/GMT+7) hingga 14 Maret 2019 pukul 14:00 waktu lokal (WIB/GMT+7) dengan interval pengukuran 15 menit pada saat pemeruman sedang berlangsung di Dermaga Pulau Sebesi. Data tersebut selanjutnya diolah menggunakan software Microsoft Excel dengan cara menghitung Duduk Tengah (DT), yang diperoleh dari pengamatan pasut selama 3 (tiga) piantan yang dimulai tanggal 14 Februari sampai 17 Februari 2019 dengan metode Admiralty. DT rata-rata $(428 \mathrm{~cm})$ Zo yang digunakan adalah 80 $\mathrm{cm}$ untuk pasut Pulau Panjang di Pulau Sebesi. Untuk data pengolahan pasut ini diambil dari pengukuran Tide Master Valeport, kemudian hasil tersebut kita buat dalam format .tid agar bisa dibaca oleh software Caris Hips and Sips seperti pada Gambar 3.4.



Gambar 3.4 Hasil Pengolahan Tide dari Caris Hips and Sips

Dari Gambar 3.4 diatas dapat dilihat bahwa pasang surut di area survei selama 29 hari merupakan tipe pasut campuran condong harian ganda. Pasut inilah yang digunakan untuk mengkoreksi hasil sounding.

\subsubsection{Pengolahan Data Sound Velocity Profile}

Pada saat akan melaksanakan pengambilan data batimetri disekitar area survei data Sound Velocity Profile diperoleh dengan menggunakan alat Valeport MIDAS SVX 2. Pengambilan data dilaksanakan pada tanggal 07 dan 08 Maret 2019, profil kecepatan suara di lokasi penelitian diperlukan untuk mengkoreksi data MBES hasil pemeruman, selain itu profil kecepatan suara ini menunjukkan data kecepatan tiap kedalaman kolom perairan. Pada saat pengolahan data koreksi kecepatan suara ini dimasukkan sesuai dengan hasil pengukuran nilai SVP di lokasi penelitian, data SVP tersebut ditampilkan dengan sound velocity editor pada Caris Hips and Sips seperti pada Gambar 3.5.

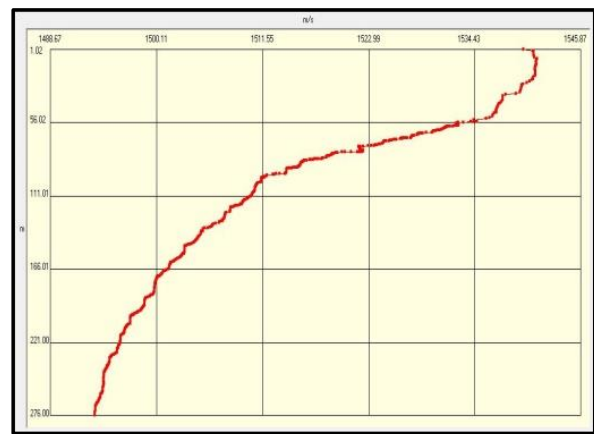

Gambar 3.5 Hasil Pengolahan SVP dari Caris Hips and Sips

Dari Gambar 3.5 diatas data SVP hasil pengolahan pada Caris Hips and Sips SVP Editor didapat bahwa SVP terendah dipermukaan, yaitu $1539.632 \mathrm{~m} / \mathrm{s}$ kemudian terjadi peningkatan pada kedalaman sampai di kedalaman 8 meter, yaitu $1540.795 \mathrm{~m} / \mathrm{s}$ seperti yang terlihat pada profile data.

Perbedaan yang terjadi pada sound velocity di setiap kedalaman dipengaruhi oleh tekanan dan suhu. Semakin tinggi suhu semakin cepat rambat suara, hal ini 
dikarenakan suhu yang tinggi membuat semakin cepat getaran-getaran partikel dalam medium tersebut, sehingga membuat proses perpindahan getaran semakin cepat. Selain suhu, tekanan juga berpengaruh terhadap sound velocity di dalam air, setiap kedalaman bertambah maka tekanan akan semakin tinggi, dan semakin tinggi tekanan akan membuat cepat rambat suara juga semakin tinggi. Hal ini dikarenakan partikel-partikel zat yang bertekanan tinggi terkompresi sehingga cepat rambat yang dihasilkan lebih besar. Pengaruh tekanan akan lebih besar dibandingkan dengan suhu pada lapisan deep layer.

\subsubsection{Konfigurasi Vessel}

Konfigurasi atau setting peralatan survei terhadap kapal survei (KRI Spical-934) digunakan untuk input pengolahan data di software Caris Hips and Sips. Setting offset peralatan echosounder, motion sensor dan GPS ke Centre Of Gravity (COG), dengan menggunakan SV KRI Spica-934 MBES EM 2040 dan KRI Spica-934 MBES EM 302 yang digunakan pada saat melaksanakan survei, bisa dilihat pada gambar dibawah ini.

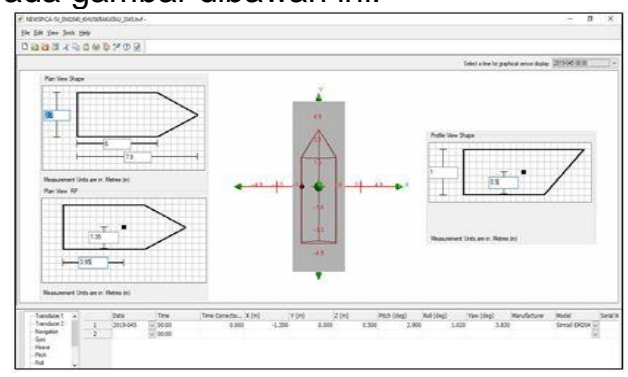

Gambar 3.6 SV MBES EM 2040 KRI Spica-934

Dari Gambar 3.6 dapat dijelaskan bahwa dimensi SV KRI Spica-934 adalah panjang SV 7.9 meter, lebar SV 2.6meter, dan draft SV 0.5 meter.

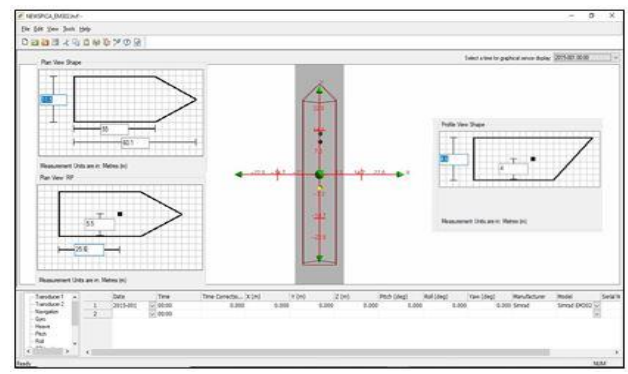

Gambar 3.7 Vessel MBES EM 302 KRI Spica-934

Dari Gambar 3.7 dapat dijelaskan bahwa dimensi KRI Spica-934 adalah panjang kapal 60.1 meter, lebar kapal 11.5 meter, dan draft kapal 4 meter.

\subsubsection{Uji Kualitas Data}

Uji kualitas data/patch test dilakukan untuk mengetahui nilai pitch, roll, yaw dan latency, dari masing-masing transducer pada
KRI Spica-934 dan SV KRI Spica-934 yang dilakukan di sekitaran Anak Gunung Krakatau, untuk SV menggunakan MBES EM 2040 dilaksanakan pada kedalaman 10m-20m, sedangkan KRI Spica-934 menggunakan MBES EM 302 dilaksanakan pada kedalaman $160 \mathrm{~m}-220 \mathrm{~m}$. Spasi antar lajur perum overlap yaitu $\pm 25 \%$ sehingga tercapai $100 \%$ seafloor full coverage area, seperti pada Gambar 3.8.



Gambar 3.8 Base Surface dan Base Surface QC Report

Dari Gambar 3.8 diatas dapat dilihat hasil quality control report dari base surface dan grafik hasil pengolahan data bathimetri setelah mendapatkan koreksi pasut sesuai standar $\mathrm{IHO}$ hasil QC report menyatakan data masuk dalam orde spesial $90.30 \%$. Batas orde spesial ditunjukkan dengan garis berwarna merah sedangkan hasil QC report ditunjukkan garis berwarna hijau. Dari grafik di atas terlihat sudut bukaan yang digunakan $-60^{\circ}$ sampai $+60^{\circ}$ menghasilkan data yang masuk orde spesial, hal ini terlihat dari garis berwarna hijau tidak ada yang melebihi / melintasi garis berwarna merah.

\subsection{Hasil dan Pembahasan Penelitian 3.3.1 Pengolahan Data Bathimetri}

Dalam proses pengolahan raw data bathimetri, software yang di gunakan adalah Caris Hips and Sips. Data yang digunakan untuk melaksanakan pengolahan menggunakan data yang diambil dari MBES EM 302 single head KRI Spica-934 dan EM 2040 dual head milik SV KRI SPICA-934 berbentuk .all file. Hasil dari pengolahan data setelah dilaksanakan beberapa proses pengolahan hingga telah dilaksanakan proses cleaning hasilnya berbentuk format .csar dan dapat dilihat pada Gambar 3.9. 


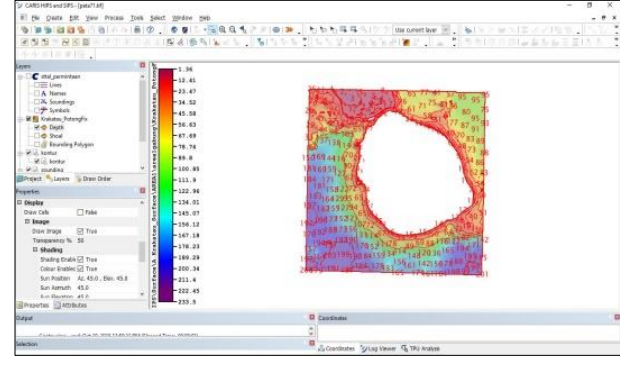

Gambar 3.9 Olahan Raw Data Anak

Krakatau Pasca Erupsi tahun 2018

Menggunakan Software Caris Hips and Sips

Dari hasil data yang sudah diolah diatas selanjutnya dioverlay dengan LLT (Lembar Lukis Teliti) Selat Sunda tahun 2016 dengan skala 1 : 100.000 dalam bentuk format file .des dari Dishidro Pushidrosal, yang selanjutnya akan kami gunakan untuk perbandingan, Kemudian file LLT tersebut dimasukkan ke software Caris Hips and Sips dengan hasil seperti pada Gambar 3.10.



Gambar 3.10 LLT (Lembar Lukis Teliti) tahun 2016 Menggunakan Software Caris Hips and Sips

\subsubsection{Hasil Analisa Perbandingan Perubahan Kontur Kedalaman Menggunakan Lembar Lukis Teliti (LLT) Tahun 2016 Dengan Base Surface Setelah Erupsi Tahun 2018}

Dari hasil overlay antara LLT dengan Base Surface hasil olahan menggunakan software Caris Hips and Sips dapat diperoleh tampilan seperti pada Gambar 3.11.

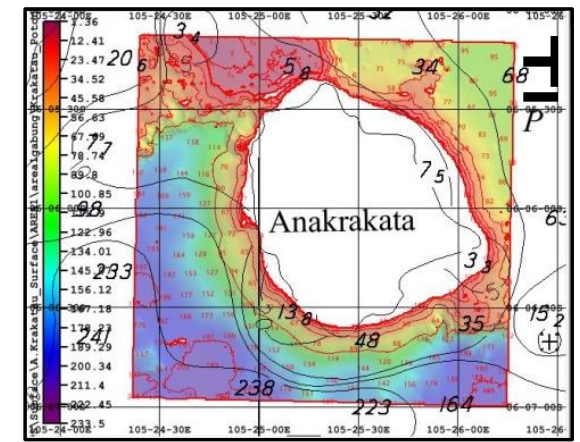

Gambar 3.11 Overlay LLT tahun 2016 dengan Base Surface hasil olahan pasca erupsi
Dari Gambar 3.11 dapat dianalisakan bagaimana perubahan kontur yang terjadi di perairan sekitaran Anak Gunung Krakatau pasca erupsi tahun 2018 dengan keterangan untuk data LLT ditandai dengan garis kontur dan angka kedalaman berwarna hitam, sedangkan data yang baru menggunakan garis kontur dan angka kedalam multi warna, dengan analisa sebagai berikut :

\section{a. Pada kontur kedalaman $\mathbf{5}$}

Pada saat sebelum terjadinya erupsi berdasarkan LLT dengan garis kontur berwarna hitam terdapat adanya kontur kedalaman $5 \mathrm{~m}$ dibagian Tenggara Anak Gunung Krakatau dengan jarak $\pm 478 \mathrm{~m}$ dari garis pantai, setelah terjadi erupsi berdasar data yang sudah diolah kontur tersebut menjadi kontur $20 \mathrm{~m}$ - $50 \mathrm{~m}$ seperti pada Gambar 3.12.

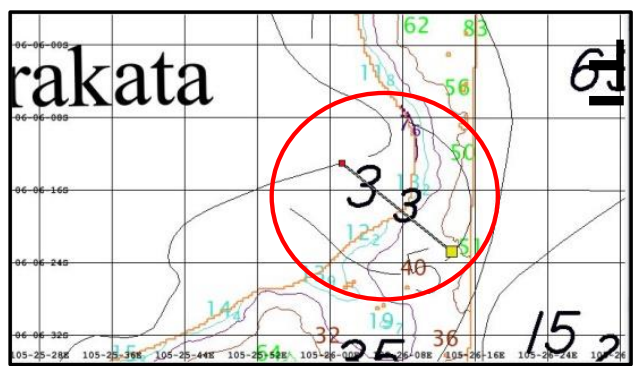

Gambar 3.12 Kontur kedalaman 5 meter bagian Tenggara

Selain itu di bagian Barat Daya berdasarkan LLT juga terdapat adanya kontur kedalaman $5 \mathrm{~m}$ dengan jarak $\pm 724 \mathrm{~m}$ dari garis pantai. Sedangkan dari data hasil olahan, kontur tersebut menjadi kontur kedalaman $5 \mathrm{~m}$ - 30 mseperti pada Gambar 3.13.

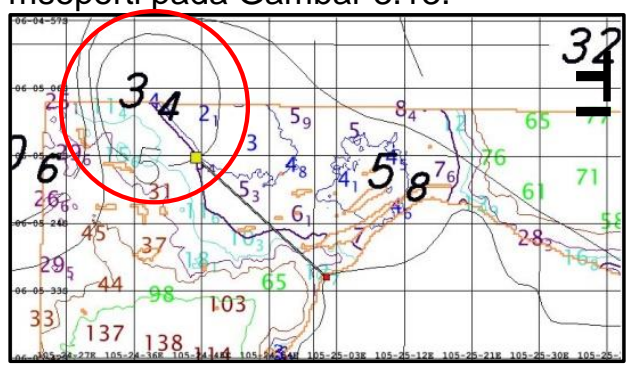

Gambar 3.13 Kontur kedalaman 5 meter bagian Barat Daya

\section{b. Pada kontur kedalaman 10}

Pada saat sebelum terjadinya erupsi berdasarkan LLT yang ditandai dengan garis kontur berwarna hitam bahwa kontur kedalaman 10 meter terdapat dibagian Utara, Timur dan Barat. Sedangkan berdasarkan data hasil olahan, kontur kedalaman $10 \mathrm{~m}$ tersebut mengalami perluasan di bagian Timur dan Utara Anak Gunung Krakatau seperti yang ditandai dengan 
lingkaran warna merah. Di bagian barat terjadi perubahan kontur di beberapa area, yang semula dari kontur kedalaman $10 \mathrm{~m}$ menjadi $30 \mathrm{~m}-200 \mathrm{~m}$ seperti pada Gambar 3.14.



Gambar 3.14 Kontur kedalaman $10 \mathrm{~m}$

\section{c. Pada kontur kedalaman $\mathbf{2 0}$}

Pada saat sebelum terjadinya erupsi berdasarkan LLT kontur 20 meter berada di bagian selatan Anak Gunung Krakatau dengan jarak $\pm 409 \mathrm{~m}$ dari garis pantai, setelah terjadi erupsi berdasar data yang sudah kami olah kontur $20 \mathrm{~m}$ tersebut mengalami perubahan menjadi kontur $20 \mathrm{~m}-200$ $\mathrm{m}$. Dari data yang kami olah, kontur tersebut mendekati garis pantai hampir diseluruh bagian Selatan Anak Gunung Krakatau yang mengakibatkan garis pantai di area tersebut mengalami penyempitan, seperti pada Gambar 3.15.

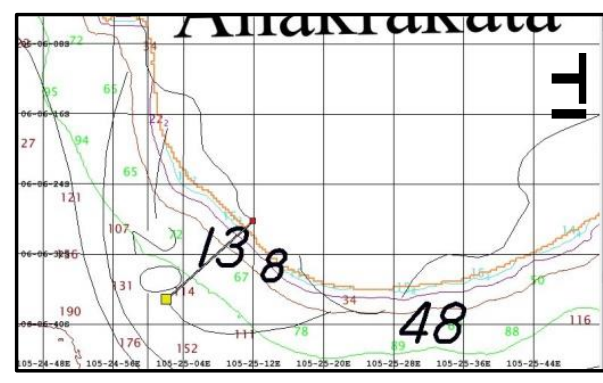

Gambar 3.15 Kontur kedalaman $20 \mathrm{~m}$

\section{d. Pada kontur kedalaman $\mathbf{3 0}$}

Pada saat sebelum terjadinya erupsi berdasarkan LLT terdapat kontur kedalam $30 \mathrm{~m}$ di bagian Barat Daya Anak Gunung Krakatau, setelah terjadi erupsi berdasar data yang sudah kami olah untuk kontur kedalaman $30 \mathrm{~m}$ di bagian Barat Daya tidak mengalami perubahan yang signifikan. Sedangkan di bagian Barat sekitar Anak Gunung Krakatau yang ditandai warna merah bahwa kontur kedalaman $30 \mathrm{~m}$ mendekati garis pantai dengan jarak $\pm 60 \mathrm{~m}$ dari garis pantai, seperti pada Gambar 3.16.

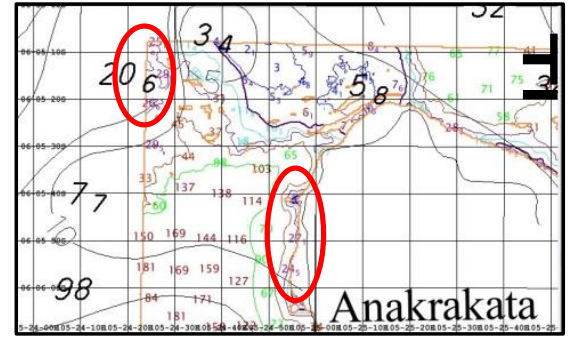

Gambar 3.16 Kontur Kedalaman $30 \mathrm{~m}$

\section{e. Pada kontur kedalaman $\mathbf{5 0}$}

Pada saat sebelum terjadinya erupsi berdasarkan LLT kontur kedalaman $50 \mathrm{~m}$ yang ditandai arah panah berwarna merah terdapat hampir di seluruh area perairan Anak Gunung Krakatau, setelah terjadinya erupsi berdasar data yang sudah kami olah untuk kontur kedalaman $50 \mathrm{~m}$ mengalami penyempitan ke arah garis pantai dan terjadi hampir diseluruh area sekitar Anak Gunung Krakatau yang ditandai dengan anak panah berwarna biru seperti pada Gambar 3.17.

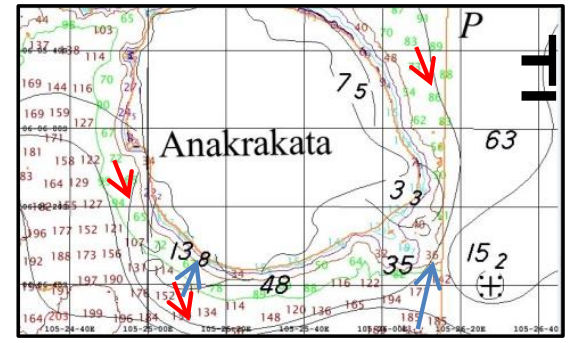

Gambar 3.17 Kontur Kedalaman $50 \mathrm{~m}$

\section{f. Pada Kontur kedalaman $\mathbf{1 0 0}$}

Pada saat sebelum terjadinya erupsi berdasarkan LLT kontur kedalaman $100 \mathrm{~m}$ terdapat hampir disemua area perairan Anak Gunung Krakatau seperti yang ditunjukkan arah panah, setelah terjadi erupsi berdasar data yang sudah kami olah untuk kontur kedalaman laut $100 \mathrm{~m}$ juga terdapat hampir diseluruh area sekitar Anak Gunung Krakatau dengan ditandai berupa garis kontur dan angka kedalaman berwarna hijau. Selain itu kontur kedalaman tersebut mendekati ke arah garis pantai dengan jarak \pm 342 m, seperti pada Gambar 3.18. 


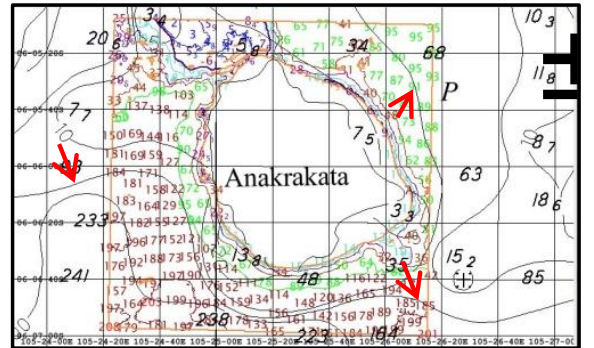

Gambar 3.18 Kontur Kedalaman

$100 \mathrm{~m}$

\section{g. Pada Kontur kedalaman 200}

Pada kontur kedalaman $200 \mathrm{~m}$ berdasarkan LLT yang ditandai anak panah warna merah dan dari data yang sudah diolah dengan garis kontur dan warna kedalaman berwarna coklat kontur tersebut terdapat di area perairan bagian barat hingga ke selatan Anak Gunung Krakatau. Disamping itu dari data hasil olahan pasca erupsi kontur kedalam $200 \mathrm{~m}$ ini mengalami penyempitan mendekati garis pantai seperti pada Gambar 3.19



Gambar 3.19 Kontur Kedalaman $200 \mathrm{~m}$

\section{h. Pada Kontur Kedalaman 300}

Pada kontur kedalaman $300 \mathrm{~m}$ terjadi penyempitan area dibandingkan dengan LLT yang mana kontur kedalaman tersebut berada di area perairan bagian Barat hingga ke Selatan Anak Gunung Krakatau, sedangkan berdasarkan base surface hasil olahan untuk kontur kedalaman $300 \mathrm{~m}$ hanya terdapat di area tertentu yaitu di bagian Barat Daya perairan Anak Gunung Krakatau denga ditandai lingkaran berwarna biru seperti pada Gambar 3.20.



Gambar 3.20 Kontur kedalaman $300 \mathrm{~m}$
Dari hasil analisa perubahan kontur kedalaman laut diatas dengan membandingkan hasil Lembar Lukis Teliti (LLT) tahun 2016 dan base surface hasil olahan Anak Gunung Krakatau pasca erupsi tahun 2018 menggunakan software Caris Hips and Sips didapat bahwa pola perubahan kontur kedalaman di perairan sekitar Anak Gunung Krakatau pasca erupsi tahun 2018 mengalami perubahan. Dibagian Utara terjadi pendangkalan dimana semula kontur kedalaman $10 \mathrm{~m}$ menjadi $5 \mathrm{~m}$, sedangkan di seluruh area pesisir/garis pantai di area Anak Gunung Krakatau kontur kedalaman rata-rata antara kontur $20 \mathrm{~m}$ hingga $30 \mathrm{~m}$, dimana sebelumnya kontur kedalamannya antara $5 \mathrm{~m}$ hingga $20 \mathrm{~m}$. Perubahan kontur yang sangat terlihat yaitu dibagian Selatan dan Barat Anak Gunung Krakatau, dimana garis pantai mengalami penyempitan yang di akibatkan terjadinya longsoran yang mengarah ke laut sehingga garis pantai mengalami perubahan.

\section{KESIMPULAN}

a. Dari hasil pengumpulan data, pengolahan data, analisis dan hasil penelitian yang telah dilakukan, maka kesimpulan yang dapat diambil dalam Skripsi ini adalah:

b. Berdasarkan data yang telah kami olah sesuai area yang kami analisa dengan menggunakan software Caris Hips and Sips perubahan kontur kedalaman di perairan sekitar Anak Gunung Krakatau pasca terjadinya erupsi tahun 2018 diperoleh hasil kontur kedalaman laut $5 \mathrm{~m}-300 \mathrm{~m}$.

c. Perbandingan perubahan kontur kedalaman sebelum terjadinya erupsi berdasarkan Lembar Lukis Teliti (LLT) sesuai area penelitian menunjukkan kontur kedalaman dimulai dari kontur $5 \mathrm{~m}$ - $300 \mathrm{~m}$ dan hanya terdapat di beberapa area, setelah dioverlay dengan data olahan pasca terjadinya erupsi tahun 2018 terjadi pendangkalan disekitar Anak Gunung Krakatau yang mendekat ke arah garis pantai, bahkan di bagian Barat dan Selatan Anak Gunung Kratau terdapat garis pantai yang mengalami penyempitan ke arah Timur dan Utara akibat terjadi longsoran yang kemudian membentuk garis pantai baru.

d. Hasil proses pengolahan data Multibeam Echosounder menggunakan software Caris Hips and Sips dapat menampilkan bagaimana perubahan kontur yang terjadi setelah erupsi Anak Gunung Krakatau dengan membandingkan menggunakan LLT (Lembar Lukis Teliti) sebelum terjadinya erupsi dengan cara mengoverlay kedua data tersebut, sehingga dapat 
memudahkan untuk mengetahui bagaimana perubahan kontur kedalaman di perairan sekitar Anak Gunung Krakatau.

\section{SARAN}

Dari analisis dan kesimpulan yang telah diperoleh, disertai dengan batasan-batasan yang ada, beberapa saran yang diajukan adalah sebagai berikut:

5 Dari hasil penelitian menunjukkan pentingnya melaksanakan pengambilan data bathimetri sesegera mungkin untuk mengetahui bagaimana perubahan kontur kedalaman di perairan sekitar Anak Gunung Krakatau pasca terjadinya erupsi untuk dilaksanakan update peta guna keselamatan pelayaran.

Perlunya dilaksanakan survei bathimetri secara berkala di seluruh area Anak Gunung Krakatau guna mengetahui kontur kedalaman laut di area tersebut, karena Anak Gunung Krakatau adalah salah satu gunung yang masih aktif.

\section{DAFTAR PUSTAKA}

https://zh.wikipedia.org.

(t.thn.). Diambil kembali dari (2006). Dipetik Juni 11, 2018, dari Kongsberg, http://digilib.itb.ac.id: http://digilib.itb.ac.id/files/disk1/622/jbptitbpp-gdldennykurni-31083-3-2008ta-2.pdf

Manual Publication Number 4 (M-4). (2008). International Hydrographic Organization (IHO).

(2015). Dipetik 2019, dari

ResearchGate:

www.researchgate.net/figure/Definition-of-shipmotion-surge-sway-heave-roll-pitch-

yaw_fig3_274095894

de Moustier, C. (1988). State of the Art in Swath Bathymetry Survey Systems." International Hydrographic Review., Volume 65 (2), pp. 25-54.

de Moustier, C. (1998). Bottom Detection Methods, Coastal Multibeam Training Course Notes.Ocean Mapping Group, Department of Geodesy and Geomatics Engineering, University of New Brunswick, pp. 6.

Djunarsjah, E. (2005). Diktat Survei Hidrografi II Pemeruman. ITB: Bandung.

E.C. Bouwmeester and A.W. Heemink. (1993). Optimal Line Spacing In Hydrographic Survey. Monaco: $\mathrm{IHO}$ in International Hydrographic Review, LXX(I).

Haryanto. (2010). Koreksi Pasang Surut. International Hydrographic Organization

(IHO). (2008). Special Publication S44 5th Edition.

$(\mathrm{SVP})$.
Kongsberg. (2013). Dalam S. I. System. Norway: Kongsberg Maritime AS.

Lekkerkerk, H.-j. R. (2006). offshore Surveing: Acquisition and Processing Volume Two. Netherland: Fugro.

Mann, R. a. (1996). Field Procedures for the Calibration of Shallow Water Multibeam Echosounding System. . Canada: Canadian Hydrograpic.

Mike. (2008). Profil kecepatan suara dalam air laut.

Poerbandono dan Djunarsjah, E. (2005). Survei Hidrografi. Bandung: PT. Refika Aditama, ITB.



Putra, A. (2017, September 15). Pusat Hidro Oseanografi TNI Angkatan Laut. Diambil kembali dari Wikipedia Indonesia: http://id.m.wikipedia.org/wiki/Pusat Hidro Oseanografi TNI Angkatan Laut

Rawi, S. (1985). Teori Pasang Surut.

Sasmita, D. K. (2008). Aplikasi Multibeam Echosounder System (MBES) Untuk Keperluan Batimetrik. Bandung: Institut Teknologi Bandung.

Sugiyono. (2003). Metodelogi Penelitian.

Universitas Indinesia, P. S. (2007). Krakatau : Laboratorium Alam di Selat Sunda. Jakarta: Pusat Survei Sumber Daya Laut Universitas Indonesia.

www.noaateacheratsea.com. (2010). 